\title{
Media Treatment on Religion Issues
}

\author{
Lutfi Basit \\ Faculty of Social Science and Political Science \\ University of Muhammadiyah Sumatera Utara \\ Medan, Indonesia \\ lutbas@yahoo.com
}

\begin{abstract}
The contestation of the 2017 regional head election of DKI Jakarta is over, but its impact on social life and religious primordial issue is still felt across Indonesia. This situation could not be separated from the way that television (media) treats primordial issues such as religion as their media streaming themes. This study aims to describe the treatment of television as the media for Islamic issues and its relation to the theory of hidden agenda setting and its adherence to journalistic ethics (independency, accuracy, and balance). The qualitative approach by extensive library research was used to do this study. Data were analyzed qualitatively to find connection media streaming, Islamic issues and the ethics. Television as media was not working properly. It was found that the television streamed important session which was not considered important by the public. Public opinion tends to put television as media for pseudo framing and propaganda of some certain groups. The study also found in many cases, the codes of ethics were violated. Media has play role on framing religious (Islamic) issues improperly by framing session with no line to journalistic ethics. This implicated to positioning television as untrusted media on religion issues and public then tends to use social media.
\end{abstract}

Keywords-media; Islam; religious issues; ethics

\section{INTRODUCTION}

The mass media is often referred to as the fourth pillar of democracy for its vital role as a political channel, enabling every citizen to know the important issue of politics and a place of reliance for information that allows the media to "organize the political agenda" for the state [1], including those related to religious issues. In the election, the media often includes religious affiliations, relationships with prominent religious leaders and the general outlook on important issues for certain religious groups of candidates. In America, Media participates and plays its role in influencing the American way of thinking towards religion [2].

In the contestation of the regional head election in DKI Jakarta, religious issues emerged along with the alleged blasphemy case committed by the Governor Basuki Tjahja Purnama when quoting the Al-Maidah verse 51 during his visit on Pramuka Island, Kepulauan Seribu on September 27, 2016. The Indonesian Ulema Council responded by issuing a fatwa that the statement is a blasphemy of religion and verses of AlQur'an. It rolled fast and echoed very broad which caused several actions led by the Moslems coalition from November 2016 to March 2017 to prosecute law enforcement against perpetrators of religious blasphemy.
The action was widely exposed by mass media including television because of several reasons, such as the case involved the Governor of Jakarta, the time adjacent to the election of DKI Jakarta, the mass involved was huge (followed by no less than 2 million people) adherents of major religions, participants of the action include groups considered as intolerant, and stigma to Muslims associated with acts of terrorism in Indonesia. This resulted in a certain discourse construction process in news and the intention of leading readers to a certain public opinion [3].

In the Post-New Order, the television industry developed significantly related to the freedom of ownership so as to make the television program content become more aligned to the interests of the media itself [4]. Some owners of mainstream TV media such as MNC group, TV One, and Media Group have proximity to authoritive power and potentially ignored the independency, accuracy, and balance aspects as set out in the ethic codes.

The aforesaid phenomena have been an interest to research the media treatment of religious issues in the Jakarta elections, by considering the continuation of the polarization effect even after the Governor election on October 16, 2017. The victory is cynically used religious issues that are considered undemocratic.

\section{RESEARCH METHOD}

The study was conducted to obtain an overview of the treatment of TV media in covering religious issues, especially Islam and its relation with agenda setting theory and obedience to journalistic ethics. This research uses qualitative method to know the relation of existing components in research. According to Bogdan and Tailor in Moleong, qualitative methods are defined as research procedures that produce descriptive data in the form of written or oral words of people and behavior that can be observed. According to them, this approach is directed to the background and individuals are holistic [5]. In addition to simplify and enrich the information in support of existing data, this study applied library research through literature study.

The collected data were then reviewed and analyzed by literature studies that include the searching of a number of data sources (literature), then the analyzed data were interpreted to find the relationship and interconnection between the components. The method of drawing conclusion in this research is deductive and will probably not contain anything 
new but it can help understand the facts about the treatment of $\mathrm{TV}$ media on Islamic religious issues.

\section{RESULT AND DISCUSSION}

\section{A. Media Independence}

In the political context, the media is able to take over the role of political parties in influencing the public. This one-way traffic communication is considered more practical without bothering the public. People remains stay or turn to their gadgets. This phenomenon is called by Michael Bauman, quoted by Burhanuddin Muhtadi as telepolitics [6].

The character of the media in Indonesia undergoes some changes over the time. In the struggle period, the mass media was positioned as a struggle press, a tool of revolution in the era of the late President Sukarno.

In the New Order period, the press should no longer be colorful and articulate the interests of certain political parties. Media positions are herded into full supporters of the government to perpetuate the power of the new order. The government controls the press by issuing mechanisms for issuing public licenses.

In the time of President Habibie, in mid-1998 the Constitution of the Principal Act was replaced by Law No. 40 of 1999 on the press. This law provided the freedom space for the press to express its thoughts and opinions, but the freedom it possesses was unable to make it completely free from alignments to power (politics and capitalists) the press experienced what Siregar called anomalimedia, where the media was not able to function as a public educator and social control for the community. Media trapped to build opinions to support the ideas and interests of the owner than to build a healthy public space to educate the public [7].

The freedom of the press should be interpreted as an existential freedom but the position of journalists as the spearhead of a press institution. In the constructionist view, reality is subjective. Reality is created because it is constructed by journalists in accordance with the views and perceptions it has [8]. The perception of journalists is formed by identities influenced by social, political, religious, and the perspective. The perception of journalists is shaped by an identity influenced by their social, political, religious, and worldview in Warren and Fassett (1974) [9].

\section{B. The Religion Issues in Jakarta Election in the Media}

The old adage claimed that "The camera never lies" according to Bauman is no longer relevant. The media, especially television, always lie through what the television called the Illusion of Presence, the camera can create an event as desired by it.

By the time and during the election process of DKI, the issue of religion was so dominantly displayed by the TV media with the Islamic blasphemy as the central issue which was originated from the speech of Governor Basuki Tjahja Purnama known as Ahok in Kepulauan Seribu on September 27, 2016 during his visit in Pramuka Island, Kepulauan Seribu. At that moment the Governor of Jakarta quoted Al-Maidah verse 51 in connection with the alleged leadership despise religion. On October 6, 2016 Buni Yani uploaded the speech recording video on her Facebook account; titled 'Blasphemy of Religion' He revealed that the video was sourced from the NKRI Media page. Shortly afterwards the Islamic Defenders Front (FPI) and the Indonesian Ulema Council reported Ahok to the police.

The Indonesian Ulema Council took a position by issuing a fatwa that Ahok's statement has been considered to be a religious defamation. There was a coalition of various Indonesian Muslim community organizations called the National Movement of Fatwa Guards of the Indonesian Ulema Council (GNPF-MUI). This coalition, which then initiated a demonstration with the name of Islamic defensive actions conducted in three volumes on October 14, 2016, November 4, 2016, and December 2, 2016. The demands were law enforcement of perpetrators of blasphemy not the election process in DKI Jakarta. In Kamath's view [10] this kind of reality has the potential to become big news because it involves elements of conflict and confrontation.

In presenting the issue of Islamic blasphemy and law enforcement demands on the Islamic Defense Action I that took place on October 14, 2016, Metro TV aired it with a title emphasizing the issue of SARA and linking it with the Jakarta regional election, through the theme of the No-SARA Race Campaign; Peaceful Regional Election Without a SARA Issue; Reject Issues of SARA and similar themes by presenting informants from Muslim leaders such as Din Syamsuddin with back ground Center for Dialogue and cooperation among civilizations. Kompas TV also displays the titles of news with SARA issues, such as the SARA Issue ahead of the Jakarta Elections; Stop SARA Issues ahead of DKI Election! This is different from the theme presented by TV One that does not offend a bit of SARA issues, the theme was more substantive 'Alleged Defamation of Religion'.

The presentation of news by Metro TV related to the Islamic Defense Action II on 4 November 2016 was connected with the election process. The theme that carried Metro TV about the plan of Demo November 4, 2016 is Silencing SARA in Jakarta Election. Contrary, TV One also remain in other topics. Metro TV show also presented Muslim intellectual Azyumardi Azra who revealed that Islamic defending is difficult to regulate because of ideology. The action is followed by Islamic defenders front (FPI) that was considered as intolerant group [4]. FPI was considered a military-backed organization that is supported by funds from special militarystyle training [11]. The FPI is based in Jakarta which is famous and controversial because its actions since 1998 often culminate in the violence shown in the mass media [12].

In the run up to the Islamic Defense Action III on December 2, 2016, in Breaking News Metro TV wrote the title of the December 2 Peace Action report, but the content began with an interview about the arrest of a supposedly treason character by Boy Rafli Amar, Police Public Relations Division Head. The captured figures are the figures who are also involved in the Islamic defense action. TV One takes on a different theme: Peaceful Action December 2, Millions of Prayers Friday at Monas. 
After the defeat of Islam, TV media kept publishing religious issues related to Islam's martial action. Metro TV was still consistently raising the issue of SARA in addition to trying to clarify accusations of Muslims against religious as well as conflicting religious issues (Islam) with diversity concept. Metro TV raised the theme Witness Fishermen Confess Did Not Hear Ahok declared Al-Maidah - and theme of Intelligent Comment of Ahok Al-Maidah Sighting-Clarification Complete Ahok on Al Maidah. In addition, SARA themes were aired on March 28, 2016.

In the other hand, diversity action with the number of participants is not as much as the participants of Islamic martial arts has been Metro TV focus and published substantively into news in several themes diversity and tolerance, such as Carnival of Indonesia Raya; Candles for NKRI and Hundreds of Citizens Participated in the Candle Lighting and the theme of Remembering the 19th Anniversary of the 1998 Tragedy, in Taman Ismail Marzuki which in action also used candles, similar to the actions performed in Palembang.

Media TV seeks to use identity theory by building identity equality. Identity is a "code", which consists of symbols, such as white clothing used in Islamic defensive actions and the use of candles on diversity, defines membership in a particular community. Our identity, both in ourselves and others, is shaped when we socially interact with others in our lives [13]. According to Michael Hecht, the knowledge of others about ourselves is based on what we do, what we say, what we have, and how we act. Our appearance is the symbols of a deeper aspect of our identity, and others will define and understand us through the appearance [14].

In relation to Habib Rizieq Shihab case, a figure in the Islamic defense, Kompas TV themed Sukmawati Check the Progress Case Alleged Pancasila insults. Metro TV, CNN, and TV One also showed cases of alleged pornographic content made by Habib Rizieq Shihab more than ten news intensely on the month May 2017. Habib Rizieq-related news themes theme systematically aired on Metro TV starting with the theme of Firza Husein Defined Suspect; Alleged Content Cases of Pornography; Cases of Alleged Pornography Rizieq Shihab; Police Set Rizieq as Suspect, so do CNN and TV One.

The themes chosen by the television are indicators of a framing. Frame has a broad meaning in all forms of effort to framing the message. Such understanding is reflected in the opinion of Entman [15] that defines Framing from a conceptual point of view. Framing can also be interpreted as a framework that affects the daily reality, the meaning of the disclosure of events and tools to promote the definition and interpretation of a particular issue [16].

Some framing done by the television media on religious issues is considered as a lie or slander. Such as Metro TV show on February 11, 2017 with the theme of Cirebon Ulema directed Citizens Not Join Action 112. This news was later clarified by Buya Yahya, a cleric from Cirebon, because the news was considered to have lied because it did not meet the elements of objectivity. Similarly, when Metro TV aired action 212 which was only followed by 50 thousand people that cause public dissatisfaction with the independence and neutrality of Metro TV, which later clarified itself by Metro TV. In a journalistic perspective there is a fundamental error committed by Metro TV journalists without mentioning the source of the news. Information does not have to account for the statement. In the standard of news feasibility, a media journalist must cross check the concerned so that the balance of the news can be accounted for [17].

According to [18] news as an institutional product is positioned to have an ideology attached to the institution. News has certain limitations to meet the element of objectivity. As an institution's product, news is susceptible to influences by other factors. The themes shown are not off the agenda of the TV media settings.

In the agenda setting theory, the main thesis is the magnitude of the public's attention to an issue is highly dependent on how much media is paying attention to the issue. The mass media is seen as having great power in influencing society. What is presented by the media that is also the memory of them [19].

Nevertheless, in reality, what was considered important by Metro TV for example, even opposed even the public accused it as a provocateur, not independent and not professional. Metro TV reporter also gained rejection of the mass of Islamic defamation gathered in Monas Jakarta, Friday 2, 2016 and denied coverage at the Grand Mosque, Medan on November 4, 2016. Boycott's in Metro TV was uploaded by Triyan Wibowo starting on December 6, 2016 even topped the rankings and became trending topic on twitter which in 1 day has received 58.152 signature.

The themes chosen by the TV media with non-substantive themes, both directly and indirectly, consciously and unconsciously show the alignment of journalists or the media in conveying their news. Public seeks to balance the source of information through social media. The most popular issue in Indonesian social media throughout 2016, which put the Ahok Case and Islamic Defense Action into the number one most popular issue. There are 279,852,000 entries in the Google search engine. The total news related to the two issues was as much as 5730, and became trending topic on twitter in 25 hashtags and keywords. In addition, several other issues also become viral such as Buni Yani, Ahok, Demo 4 November, and Action 212.

\section{CONCLUSION}

The primordial issue of religion on the contestation of the 2017 Jakarta Regional Head Election occurred after Ahok's Speech is considered to have despised religion, leading to an Islamic Defense Action demanding law enforcement. The action has caused a sharp controversy in the community. It cannot be separated from the way the TV media treats the primordial issue, especially religion.

Television media treats religious issues objectively through news framing that obscures reality and substantive facts, is inconsistent with journalistic code of ethics related to independency, accuracy, and balance which tend to be a pseudo framing and a particular group propaganda tool that causes a sharp division among the people. Media TV News has acted in a discriminatively against the issue of Islam that has 
always been linked to the Election of Regional Head and SARA issues compared with other issues with the theme of diversity. The media did not present a substantive religious issue and discourage it, while the issue of diversity was raised.

Television as media was not working properly. It streamed important session which was not considered important by the public. Some people's reaction in several moments has proven it. The desired agenda-setting goal is not working properly

The authorities did not take action as expected by the community against indications of violation of journalistic ethics code. The implication is that the community turns to social media to meet the information needs related to religious issues that occur simultaneously with the implementation process of DKI Jakarta election.

\section{REFERENCES}

[1] Sen, Krishna and David T. Hill, "Media, Culture, and Politic in Indonesia", Jakarta \& Kuala Lumpur, Equinox Publishing, 2007. pp. 51

[2] Mohammad, Nadia S., "Bisakah Media AS Temukan Titik Kesamaan dalam Agama dan $\quad$ Politik", http://www.commongroundnews.org/article.php?id=31900\&lan=ba\&sp $=1$ artikel elektronik. 2014.

[3] Ayani, Budi, "Islam Politik dalam Media Massa", In Right, Jurnal Agama dan Hak Asasi Manusia, Vol. 5 No. 1 November 2015, 2015. pp. 44

[4] Budiasa, Meistra, "Mediatisasi Aksi Masa Islam 2 Desember 2016", Profetik Jurnal Komunikasi, Vol. 10/No.01/April 2017, 2017. pp. 43

[5] Moleong, Lexy J., "Metodologi Penellitian Kualitatif", Bandung: Remaja Rosda Karya, cet. Ke-III, 1991. pp. 3

[6] Muhtadi, Burhanuddin, "Perang Bintang 2014; Konstelasi dan Prediksi Pemilu dan Pilpres", Jakarta, Noura Books, pp. 15. 2013.
[7] Siregar, Ashadi (Pengantar), "Politik Editorial Media Indonesia", Jakarta, LP3ES, 2003. pp. xx

[8] Eriyanto, "Analisis Framing, Ideologi, dan Politik Medan", Yogyakarta, LKiS, 2002. pp. 19

[9] Warren, John T and Deanna L. Fassett, "Communication; A Critical Cultural Introduction", California, Sage, 2011. pp. 61-63

[10] Kamath, MV., "Profesional Journalism". New Delhi: Vikas Publishing House PVT LTD, 1980. pp. 94.

[11] Jahroni, Jajang, "Defending the Majesty of Islam: Indonesia's Front Pembela Islam 1998-2003", Washington, University of Washington Press, 2008, pp. 18

[12] Niam, Khoirun, "Ormas Islam dan Isu Keislaman di Media Massa, Jurnal Komunikasi Islam", ISBN 2088-6314, Volume 4, Nomor 02, Desember 2014, 2014. pp. 245

[13] Littlejohn, Stephen W. and Karen A Foss, "Theories of Human Communication, Belmont", USA: Thomson Wadsworth, 2008. pp. 894

[14] Hecht, Michael et al., "The Communication Theory of Identity: Development, Theoritical Perspective, and Future Direction, dalam Theorizing Interpersonal Communication”, ed., William B, Gudykunts Thousand Oaks, CA: Sage, 2005. pp. 257-258

[15] Entman, Robert M., "Framing: Toward clarification of a Fractured Paradigm, Journal of Communication", Vol. 43, No. 4, 1993. pp. 51-58

[16] Chong, Denis and James N. Druckman, "Framing Theory", archived on http://faculty.wcas.northwestern.edu/ jnd260/framing_theory.pdf 2007

[17] Sukarno, Adam W., "Dilema Peliputan Terorisme dan Pergeseran Pola Framing Berita Terorisme di Media Masa", Jurnal Ilmu Sosial dan Ilmu Politik, Vol. 14, Nomor 3, Maret 2011 (333-348), ISSN 1410-4946, 2011. pp. 339

[18] McQuail, Denis, "Teori Komunikasi Massa Suatu Pengantar", Translated by A. Dharma dan A. Ram, Jakarta: Erlangga, 1989. pp. 86

[19] Hamad, Ibnu, "Konstruksi Realitas Politik dalam Media Massa, Sebuah Studi Critical Discourse Analysis terhadap Berita-berita Politik", Granit, Jakarta, Cet. 1, 2004. pp. 24 